\title{
\begin{tabular}{l|l} 
Jurnal Eksplorasi Akuntansi \\
Vol. 1, No 3, Seri F, Agustus 2019, Hal 1494-1509
\end{tabular} \mid $\begin{aligned} & \text { ISSN : 2656-3649 (Online) } \\
& \text { http://jea.ppj.unp.ac.id/index.php/jea/issue/view/13 }\end{aligned}$
}

\section{PENGARUH TEKANAN ANGGARAN, AMBIGUITAS PERAN, OPPORTUNISTIC BEHAVIOUR, DAN SELF ESTEEM TERHADAP BUDGETARY SLACK}

(Studi Empiris Pada OPD Kota Bukittinggi Tahun 2019)

\author{
Jheny Steffani Gusti ${ }^{1}$, Efrizal Sofyan ${ }^{2}$ \\ ${ }^{1)}$ Alumni Jurusan Akuntansi Fakultas Ekonomi, Universitas Negeri Padang \\ ${ }^{2)}$ Jurusan Akuntansi Fakultas Ekonomi, Universitas Negeri Padang \\ *Korespondensi: jhennysteffanny@gmail.com
}

\begin{abstract}
The purpose of this study was to determine the influence budgetary pressure, role ambiguity, opportunistic behaviour and self on the Budgetary slack. The population in this studyare all OPD in Bukittinggi as many as 29 OPD. The sample in this study using asampling technique total sampling. The methods use descriptive statistic analysis and multiple linear regression. The results showed that budgetary pressure has no effect onbudgetary slack. Role ambiguity has no effect on budgetary slack. Opportunistic behaviour has no effect on budgetary slack and also self esteem effected on budgetary slack.
\end{abstract}

Keywords: Budget Pressure; Role Ambiguity; Opportunistic Behaviour; Self Esteemand; Budgetary slack

How to cite (APA $6^{\text {th }}$ style)

Gusti, J.S., \& Efrizal, S. (2019). Pengaruh Tekanan Anggaran, Ambiguitas Peran, Opportunistic Behaviour, dan Self Esteem terhadap Budgetary Slack (Studi Empiris pada OPD Kota Bukittinggi Tahun 2019). Jurnal Eksplorasi Akuntansi, 1(3), Seri F, 14941509.

\section{PENDAHULUAN}

Anggaran pemerintah ialah suatu arsip absah dari hasilkesepakatan antara eksekutif dengan legislatif tentang belanja yang ditetapkan agar kegiatan pemerintah dan pendapatan terjalankan sesuai dengan yang diharapkan untuk menutup kebutuhan belanja atau pembiayaan yang dibutuhkan saat diperkirakan akan timbul defisit atau surplus (Ratmono 2015:3). Penyusunan anggaran (Pemerintah) sektor publik ini melibatkan banyak pihak, mulai dari manajemen tingkat atas hingga manajemen tingkat bawah. Perilaku positifyang timbul yaitu berupa peningkatan kinerja manejer yang disebabkankarena adanya rasa termotivasi oleh anggaran yang digunakan sebagai dasar penilaian kinerja manejer tersebut. Sebaliknya, perilaku negatif yangmungkin timbul ialah kecenderungan manejer untuk mewujudkan budgetary slack.

Menurut Anthony (2005), budgetary slack merupakan perbedaan antara jumlah anggaran dan estimasi terbaik dari organisasi. Budgetary slack dapat dikatakan sebagai suatu kesenjangan yang dilakukan oleh manajer ketika manajer turutberpartisipasi dalam penyusunan anggaran, dengan memberikan usulandan estimasi anggaran yang tidak sesuai dengan kapasitas sebenarnya 
yangdimiliki, atau tidak sesuai dengan sumber daya yang sebenarnya dibutuhkan, dengan maksud agar anggaran tersebut mudah direalisasikan.

APBD Kota Bukittinggi memperlihatkan terjadinya kesenjangan anggaran. Senjangan anggaran ini dapat diketahui melalui tingginya angka anggaran pendapatan daerah dibandingkan realisasi pendapatan daerah yang telah ditetapkan dan juga dapat dilihat dari angka realisasi belanja daerah yang lebih rendah darianggaran belanjanya. Fraud yang ditunjukan diduga adalah senjangan anggaran, yang merendahkan pendapatan dan menaikkan biayasehingga selalu bisa tercapai dan kinerjanya terlihat baik. Persoalan-persolan senjangan anggaran terjadi karena perhatianyang tidak memadai terhadap pembuat keputusan, komunikasi, prosespersetujuan anggaran dan kepemimpinan yang tidak selektif (Apriyandi,2011). Permasalahan ini sering diidentifikasi dengan anggaran pemerintah. Oleh karena itu peneliti di bidang anggaran pada pemerintah daerah,menjadi relevan dan penting.

Faktor pertama yang menyebabkan terjadinya kesenjangan yaitu tekanan anggaran faktor yang kedua adalah ambiguitas peran. Peneliti menambahkan ambiguitas peran karena merupakan variabel baru yang masih sedikit ataujarang diteliti dalam hubungannya dengan senjangan anggaran. Faktor yang ketiga adalah opportunistic behaviour. Maryono (2013) menyatakan bahwa opportunistic behaviour merupakan perilaku yangberupaya agar tujuannya tercapai dengan berbagai macam cara bahkan ilegal sekalipun. Faktor keempat adalah self esteem. Atwater dan Duffy (1990) mengemukakan bahwa self esteem merupakan cara individu merasakan dirinya sendiri, dimana seseorang akan menilai tentang dirinya sehingga mampu mempengaruhi perilaku dalam kehidupan sehari-hari.

Maka bedasarkan fenomena yang telah dipaparkan di atas dan dengan melihat inkonsistensi pada penelitian yang telah dilakukan sebelumnya, peneliti tertarik untuk melakukan penelitian dengan judul "Pengaruh Tekanan Anggaran, Ambiguitas Peran, Opportunistic Behaviour dan Self Esteem terhadap Budgetary Slack".

\section{REVIU LITERATUR DAN HIPOTESIS}

\section{Agensi Teori}

Teori agensi merupakan konsep teori untuk memulai penjelasan konsep senjangan anggaran. Adanya konflik kepentingan antara agen (manajemen) dengan principal yang timbul ketika setiap pihak berusaha untuk mencapai atau mempertahankan tingkat kemakmuran yang dikehendakinya mempengaruhi praktik senjangan anggaran dalam prespektif teoriagensi. Latuheru (2005) telah menjelaskan bahwa teori keagenan ini membahas hubungan antara principal dan agen.

Darmawanti (2013) berpendapat bahwa teori keagenan mampu mengatasi dua permasalahan dalam hubungan keagenan. Pertama, adalah masalah keagenan yang timbul ketika (a) adanya keinginan dan tujuan yang bertolak belakang antara principal dan agen, dan (b) kesulitan principal dalam memverifikasi apa yang sesungguhnya sedang dikerjakan manajemen. Kedua, permasalahan pembagian resiko akibat perbedaan sikap principal dan agen.

\section{Kontigensi Teori}

Pendekatan kontigensi adalah cara berpikir komparatif berdasarkan perbandingan antara teori manajemen yang dikenal. Menurut Fred Luthans dalam Arimahfuddin (2013), pendekatan kontigensi adalah upaya untuk menentukan dimana kegiatan penelitian, praktik dan teknik manajemen yang paling tepat dalam situasi tertentu. 


\section{Anggaran}

Nordiawan dkk (2009), anggaran adalah sebuah proses yang dilakukan oleh organisasi sektor publik untukmengalokasikan sumber daya yang dimilikinya ke dalam kebutuhan-kebutuhan yang tidak terbatas. Pengertian tersebut menjelaskan peran strategis anggaran dalam pengelolaan kekayaan sebuah organisasi publik. Anggaran sektor publik merupakan instrumen akuntabilitas atas pengelolaan dana publik dan pelaksanaan program-programyang dibiayai dengan uang publik (Mardiasmo, 2002).

Rudianto (2009) berpendapat bahwa, karakteristik anggaran meliputi, dinyatakan dalam satuan moneter, umumnya mencakup periode satu tahun, berisi komitmen manajemen, proposal anggaran disetujui oleh pejabat yang lebih unggul dari pada pelaku anggaran. Oleh karena itu tidak dapat diubahkapan saja dan dalam segala keadaan sehubungan dengan anggaran. Jika terjadi penyimpangan dalam implementasi, analisis terlebih dahulu penyebabnya.

Dalam suatu organisasi anggaran terdapat beberapa manfaat bagi yang mengimplementasikannya. Nafarin (2015) berpendapat bahwa anggaran memiliki beberapa manfaat seperti, seluruh kegiatan yang dilakukan dapat mengarah pada pencapaian tujuan bersama, dapat digunakan sebagai alat untuk menilai kelebihan dan kekurangan karyawan, bisa menjadi motivasi bagi karyawan, dapat menggunakan sumber daya yang dimiliki, seperti tenaga kerja peralatan,dan keuangan seefisien mungkin. Bagi para manajer, dapat digunakan sebagai alat pendidikan.

Segala yang dilakukan perusahaan memiliki tujuan yang diiginkan, tidak hanya untuk penganggaran saja. Nafarin (2015) mengidentifikasi bahwa tujuan anggaran adalah, dapat digunakan sebagai basis atau pedoman untuk memilih sumber dan penggunaan data, memberikan batasan jumlah dana yang akan diperoleh dan digunakan, memberikan perincian tentang jenis sumber pendanaan yang dicari atau jenis penggunaan dana. Lebih banyak menjelaskan sumber dan penggunaandana sehingga mampu untuk mencapai hasil maksimal.

Pada saat ini, anggaran memiliki peran penting bagi suatu organisasi. Anggaran memiliki banyak keunggulan yang berguna untuk mencapai suatu organisasi seperti yangdijelaskan oleh Tendi Haruman dan Sri Rahayu (2007:7), yaitu, "Hasil yang diharapkan dari rencana tertentudiproyeksikan sebelum rencana tersebut diimplementasikan". Selain memiliki banyak manfaat, anggaran juga memiliki beberapa kelemahan. Menurut Nafarin (2015), beberapa kelemahan yang timbul dari suatu anggaran adalah sebagai berikut, Anggaran dibuat berdasarkan dugaan atau estimasi danasumsi dari suatu organisasi atau perusahaan, sehingga mengandung unsur ketidakpastian, Dalam proses anggaran yang tepat dan akurat dibutuhkan waktu, uang, energi yang cukup besar, yang berati tidak seluruh perusahaan memiliki kemampuan untuk

menyiapkan kemapuan untuk menyiapkan anggaran yang lengkap (komprehensif), tepat dan akurat.

\section{Budgetary Slack}

Budgetary Slack merupakan suatu fenomena yang terjadi pada saat proses perencanaan anggaran, pada waktu seseorang diberi kesempatan untuk berpartisipasi dalam menyatakan target anggaran maka dia tidak akan membuat target sesuai kemampuan optimalnya, akan tetapi membuatanggaran yang mudah dicapai. Hal ini terjadi akibatadanya sumber daya dari anggaran yang telah direncanakan dan diusahakan tidak bisa dicapai organisasi.

Pratama (2013) mengemukakan bahwa dalam Budgetary Slack terdapat beberapa indikator, seperti, perbedaan anggaran dengan estimasi terbaik, dispensasi dalam anggaran, kriteria anggaran, keinginan untuk mencapai tujuan. Samad (2009) berpendapat bahwa terdapat 
tiga alasan yang bisa membuat bawahan menjalankan Budgetary Slack yaitu, Budgetary Slack mampu membuat kinerja bawahan terlihat baik pada saat target anggaran yang diusulkan tercapai. Untuk mengatasi ketidakpastian di masa depan, maka dapat menggunakan kesenjangan, Budgetary Slack mampu menimbulkan alokasi sumberdaya yang fleksibel berdasarkan proyeksi anggaran.

Tekanan anggaran adalah tindakan yang memiliki pengaruh langsung pada tingkah laku manusia, terutama yang terlibat dalam proses penganggaran (Triana et al, 2012). Tekanan anggaran adalah dorongan atasan kepada bawahan untuk mengimplementasikan anggaran yang dibuat dengan baik (Nopriyanti, 2016). Pratama (2013) mengemukakan bahwa dalam Budgetary Slack terdapat beberapa indikator seperti, perbedaan anggaran dengan estimasi terbaik, dispensasi dalam anggaran, kriteria anggaran, keinginan untuk mencapai tujuan.

\section{Ambiguitas Peran}

Kreitner dan Kinicki (2014) menyatakan bahwa ambiguitas peran adalah pengharapan orang lain yang tidak diketahui. Ambiguitas peran muncul karena kurangnya informasi/tidak adanya informasi yang disampaikan (Cahyono, 2008). Ketika tidak ada kepastian mengenai penjelasan kerja dan apa yang diharapkan dari pekerjaannya akan timbul ambiguitas peran (Rivai dan Mulyadi, 2011. Sedangkan ambiguitas peran menurut Luthans (2011:350) terjadi ketika individu karyawan tidak memperoleh kejelasan mengenai tugas-tugas dari pekerjaannya atau lebih umum dikatakan "tidak tahu apa yang seharusnya dilakukan”.

\section{Opportunistic Behavior}

Sebutan opurtunistik berasal dari kata opportunity yang berarti peluang atau kesempatan. Perilaku opurtunistik mengarah pada dinamika sekelompok orang ketika dihadapkan pada suatu keadaan dimana dalam kedudukan tertentu, ia merasa memiliki peluang atau lebih untuk melakukan sesuatu sesuai dengan keinginannya. Perilaku opurtunistik adalah perilaku yang mencoba untuk mencapai ambisi dengan segala macam cara, meskipun dengan cara ilegal atau terlarang. Selanjutnya, Maryono (2013) menyatakan bahwa faktor yang mempengaruhi perilaku opurtunistik adalah kekuatan dan kompetensi.

\section{Self Esteem}

Menurut Maslow (dalam Alwisol, 2009), self esteem adalah kebutuhan manusia yang membutuhkan pelampiasan atau kepuasan untuk melanjutkan pada tingkat kebutuhan yang lebih tinggi. Kebutuhan menurut Maslow untuk self esteem dibagi menjadi dua jenis, yaitu harga diri dan menghargai orang lain. Coopersmith (1990) menyatakan bahwa ada empat factor self esteem individu. Faktor-faktor ini adalah power, significance, virtue, dan competence.

Pribadi yang memiliki self esteem yang tinggi cenderung puas dengan karakter dan kompetensi mereka. Adanya penerimaan dan reward terhadap hasil yang positif maka dapat memberikan rasa aman dalam adaptasi positif yang memberi rasa aman dalam adaptasi atau reaksi terhadap stimulus dan lingkungan sosial. Orang dengan self esteem yang rendah menyimpan perasaan percaya diri dan tanda-tanda dalam dirinya. Hal inimenyebabkan bahwa individu tidak dapat mengungkapkan diri mereka dalam lingkungan sosial mereka. Puspitasari (2006), orang- orang dengan self esteem tinggi umumnya memiliki pengetahuan diri yang lebih baik daripada orang-orang dengan self esteem rendah. Self esteem yang tinggi berpengaruh bagi semua orang, itu dapat menjadi efektif, produktif, dan dapat terhubung dengan orang lain dengan 
cara yang sehat dan positif. Oleh karena itu, setiap orang harus mengalami dirinya sebagai orang yang berguna, mampu menguasai tugas dan mampu menghadapi rintangan kehidupan.

\section{METODE PENELITIAN Jenis Penelitian}

Berdasarkan rumusan masalah dan tujuan yang telah dijelaskan pada bab sebelumnya, maka penelitian ini tergolong penelitian kausatif, dimana penelitian ini bertujuan untuk menganalisis seberapabesar pengaruh suatu variable terhadap variable lainnya (Sugiyono, 2004).Penelitian ini berusaha menjelaskan pengaruh tekanan anggaran, ambiguitas peran, opportunistic behavior, self esteem, sebagai variable independen terhadap budgetary slack.

\section{Populasi dan sampel}

Populasi dalam penelitian ini adalah Organisasi Perangkat Daerah (OPD) yang ada di Kota Bukittinggi. Berdasarkan data yang diperoleh dari Situs Resmi Kota Bukittinggi terdapat berjumlah 29 OPD yang terdiri dari Dinas, Badan, Kantor Kecamatan, dan Inspektorat. Peneliti menjadikan seluruh populasi tersebut sebagai sampel (total sampling), karena jumlah populasi kurang dari 100 subjek. Responden dalam penelitian ini terdiri dari pegawai sub bagian masingmasing OPD. Jadi jumlah responden dalam penelitian ini sebanyak 137 responden.

\section{Jenis dan Sumber Data}

Jenis data yang digunakan dalam penelitian ini yaitu data kuantitatif yang merupakan data yang berbentuk angka atau data kualitatif yang diangkakan (Sugiyono, 2009). Jenis data yang digunakan dalam penelitian ini adalah data kuantitatif yaitu data yang berupa angka-angka yang dapat dihitung atau diukur secara nyata seperti perhitungan jumlah pegawai dan jumlah jawaban responden terhadap kuesioner yang diberikan. Sumber data dalam penelitian ini adalah data primer. Kuncoro (2003) menyatakan bahwa data primer merupukan data yang diperoleh dengan survei lapangan yang menggunakan semua metode pengumpulan data original.

\section{Metode Pengumpulan Data}

Metode pengumpulan data adalah cara yang digunakan untuk memperoleh data penelitian. Dalam penelitian ini teknik yang digunakandalam pengumpulan data yaitu kuesioner atau angket. Kuesioner atau angket adalah suatu metode pengumpulan data yang berupa rangkaian daftar pernyataan yang ditujukan kepada setiap responden yang telahdisusun secara sistematis untuk mendapat jawaban yang berkaitan dengan data yang dibutuhkan dalam penelitian.

\section{Variabel Penelitian dan Definisi Operasional Variabel}

Variabel-variabel yang dianalisis dalam penelitian ini antara lain:

a) Variabel bebas (independent variable)

Variabel bebas yang digunakan dalam penelitian ini adalah tekanan anggaran, ambiguitas peran, opportunistic behavior dan self esteem.

b) Variabel terikat (dependent variable)

Variabel terikat yang digunakan dalam penelitian ini adalah senjangan anggaran. 


\section{Definisi Operasional Variabel}

Definisi operasional adalah aspek penelitian yang memberikan informasi kepada kita tentang bagaimana cara mengukur variabel.

a) Tekanan Anggaran

Tekanan anggaran terjadi pada pegawai dalam suatu instansi pemerintahan yang memiliki tekanan saat pegawai tersebut bekerja, beraktivitas, dan berkontribusi terhadap instansi perusahaan.

b) Ambiguitas Peran

Ambiguitas peran merupakan seseorang yang tidak memiliki orientasi pekerjan dengan jelas karena kekurangan informasi yang akurat, data yang kurang lengkap, hingga pekerjaan yang dihasilkan kurang optimal.

c) Opportunistic Behavior

Opportunistic behavior dapat dikatakan sebagai perilaku yang mendapatkan kesempatan dari berbagai cara meski dengan cara yang kurang baik atau ilegal sekalipun.

d) Self Esteem

Self esteem dapat dikatakan sebagai sikap yang memiliki keyakinan dan kepercayaan diri dengan segala kemampuan, keahlian dan pengetahuan.

\section{Uji Hipotesis}

\section{Uji Instrumen Penelitian}

Uji validitas digunakan untuk mengukur sah atau validtidaknya suatu kuesioner. Suatu kuesioner dikatakan valid jikapernyataan pada kuesioner mampu mengungkapka sesuatu yang akan diukur oleh kuesioner tersebut (Ghozali, 2007:45). Pengujian reliabilitas atau keandalan instrumen adalah sejauhmana suatu pengukuran dapat memberikan hasil yang konsisten bila dilakukan pengukuran kembali terhadap gejala yang sama (Sugiyono, 2006).

\section{Uji Asumsi Klasik}

Pengujian asumsi klasik bertujuan untuk melihat kelayakan model serta untuk mengetahui apakah terdapat pelanggaran asumsi klasik dalam model regresi berganda, karena model regresi yang baik adalah model yang lolos dari pengujian asumsi klasik.

a) Uji Normalitas

Pengujian normalitas data dalam penelitian ini dilakukan dengan menggunakan one sample Kolmogorov - smirnov test dengan melihat tingkat signifikan 5\%.

b) Uji Multikoliniearitas

Multikolinearitas adalah situasi adanya korelasi variabel-variabel bebas antara satu dengan yang lainnya, maka salah satu variabel bebas tersebut dieliminir.

c) Uji Heterokedastisitas

Untuk menguji apakah dalam sebuah model regresi terjadi ketidaksamaan atas suatu pengamatan ke pengamatanlain. Untuk mendeteksi adanya heterokedastisitas dapat menggunakan uji Gletser.

\section{G. Teknik Analisis Data}

\section{Analisis Deskriptif}

Digunakan untuk menggabarkan perolehan hasil penelitian berkaitan dengan perkembangan variabel-variabel yang diteliti, baik variabel bebas maupun variabel terikat. 


\section{Metode Analisis}

a) Analisis Regresi Berganda

Analisis regresi linier berganda digunakan untuk memcahkan rumusan masalah yang ada, yaitu untuk melihat pengaruh diantara kedua variabel atau lebih.

b) Uji F (Uji Siginifikansi Simultan)

Uji $\mathrm{F}$ adalah uji yang dilakukan untuk mengetahui pengaruh variable independen secara bersama-sama terhadap variabel dependen. Prosedur pengujiannya yaitu dengan melihat nilai signifikansi pada hasil uji statistik.

c) Uji t (Uji Signifikansi Parsial)

Pengujian hipotesis dilakukan dengan uji t, yaitu menguji pengaruh antara variabel independen terhadap variabel dependen, dengan asumsi bahwa variabel lain dianggap konstan.

d) Uji Koefisien Determinasi $\left(\mathrm{R}^{2}\right)$

Uji ini bertujuan untuk mengukur seberapa jauh kemampuan model dalam menjelaskan variabel terikat. Koefisien determinasi $\left(\mathrm{R}^{2}\right)$ menunjukan proporsi yang dijelaskan oleh variabel bebas dalam model terhadap variabel terikatnya, sisanya dijelaskan oleh variabel lain yang tidak dimasukkan dalam model, formulasi model yang keliru dan kesalahan eksperimen.

\section{HASIL DAN PEMBAHASAN}

\section{Gambaran Umum Objek Penelitian}

Sampel dalam penelitian ini adalah aparat pemerintah kota Bukittinggi yang terdiri dari 137 responden. Untuk dinas dan kecamatan yang berjumlah 29 OPD, dan disebar terdiri dari pegawai sub bagian dan staff. Dari 137 kuesioner yang disebar tersebut terdapat 29 responden yang tidak mengembalikan kuesioner, sehingga jumlah sampel yang diteliti sebanyak 108 responden. Gambaran penyebaran dan pengembalian kuesioner dapat dilihat pada tabel 4.1 berikut:

Tabel 4.1

Penyebaran kuesioner

\begin{tabular}{|c|c|}
\hline Keterangan & Jumlah kuesioner \\
\hline Jumlah kuesioner yang disebar & 137 \\
\hline Jumlah kuesioner yang kembali & 108 \\
\hline Jumlah kuesioner yang diolah & 108 \\
\hline Respon Rate & $78,83 \%$ \\
\hline
\end{tabular}

Sumber : Data primer yang diolah, 2019

\section{Demografi Responden}

Berdasarkan kuesioner yang dikumpulkan, diperoleh data tentang jenis kelamin responden. Adapun secara lengkap data tentang responden berdasarkan jenis kelamin ini tersusun dalam Tabel 4.2 sebagai berikut. 
Tabel 4.2

Jumlah Responden Berdasarkan Jenis Kelamin

\begin{tabular}{|l|c|c|}
\hline \multicolumn{1}{|c|}{ Jenis Kelamin } & Jumlah & Persentase \\
\hline Laki-laki & 47 & $43,51 \%$ \\
\hline Perempuan & 61 & $56,48 \%$ \\
\hline Jumlah & $\mathbf{1 0 8}$ & $\mathbf{1 0 0 \%}$ \\
\hline
\end{tabular}

Sumber : Data primer yang diolah, 2019

Tingkat pendidikan yang dimaksudkan disini adalah pendidikan terakhir yang dijalani oleh responden. Adapun secara lengkap data tentang jumlah responden berdasarkan tingkat pendidikan yang digunakan tersusun pada Tabel 4.3 sebagai berikut:

Tabel 4.3

Karakteristik Responden Berdasarkan Pendidikan

\begin{tabular}{|c|c|c|}
\hline Tingkat Pendidikan & Jumlah & Persentase \\
\hline SMA/ setingkat & 1 & $0,92 \%$ \\
\hline D3 & 10 & $9,26 \%$ \\
\hline S1 & 54 & $50 \%$ \\
\hline S2 & 43 & $39,81 \%$ \\
\hline S3 & 0 & \\
\hline Jumlah & 108 & $100 \%$ \\
\hline
\end{tabular}

Sumber : Data primer yang diolah, 2019

\section{Deskripsi Hasil Penelitian \\ Budgetary Slack}

Dari 108 responden yang diteliti terlihat bahwa tingkat capaian responden tertinggi yaitu pada item pernyataan nomor 4, yaitu dengan nilai 59,6\% dengan kategori cukup. Hal ini menunjukan standar belanja anggaran tidak langsung mendorong instansi pemerintah Kota Bukittinggi untuk meningkatkan pencapaian target anggaran (meningkatkan produktivitas) pada bidang tanggung jawab pihak instansi sehingga pihak instansi tidak perlu melakukan budgetary slack. Sedangkan tingkat capaian responden terendah pada item pernyataan nomor 1, dimana anggaran yang $\mathrm{m} 2$. enjadi tanggung jawab tidak begitu tinggi tuntutannya, dengan nilai $64,85 \%$. Untuk rata-rata tingkat capaian responden variabel ini adalah $73 \%$.

\section{Tekanan Anggaran}

Dari 108 responden yang diteliti terlihat bahwa tingkat capaian responden tertinggi yaitu pada item pernyataan nomor 2 , yaitudengan nilai $82,22 \%$ dengan kategori sangat baik. Hal ini menunjukan anggaran yang ditetapkan digunakan sebagai tolak ukur kinerja di OPD Kota Bukittinggi. Sedangkan tingkat capaian responden terendah pada item pernyataan nomor 6 yaitu berkaitan dengan pernyataanterdapat sanksi ketika target anggaran tidak dapat dicapai, dengan nilai $63,70 \%$ dengan kategori baik.

\section{Ambiguitas Peran}

Berdasarkan tabel distribusi frekuensi variabel di atas, dari 108 responden yang diteliti terlihat bahwa tingkat capaian responden tertinggi yaitu pada item pernyataan nomor 3, yaitu62,22\% dengan kategori baik. Hal ini menunjukan bahwa para karyawan/pegawai di Instansi OPD Kota 
Bukittinggi kurang yakin dengan wewenang yang dimiliki saat ini. Sedangkan tingkat capaian responden terendah pada item pernyataan nomor 1 yaitu dengan pernyataansaya merasa kurang mengetahui dengan jelas tanggung jawab saya dalam instansi, dengan nilai $54,44 \%$. Tingkat capaian rata-rata dari ambiguitas peran adalah sebesar 57,04\%.

\section{Opportunistic Behaviour}

Berdasarkan tabel distribusi frekuensi variabel di atas, dari 108 responden yang diteliti terlihat bahwa tingkat capaian responden tertinggi yaitu pada item pernyataan nomor 1, yaitunilai $80 \%$ dengan kategori sangat baik. Hal ini menunjukan bahwa para karyawan/pegawai pada instansi di Kota Bukittinggi mengetahui apa yang dapat dicapainya yang menjadi tanggung jawabnya. Sedangkan tingkat capaian responden terendah pada item pernyataan nomor 3 , dengan pernyataankeputusan dan tindakan instansi merupakan usaha untuk mempertahankan status quo, dengan nilai 58,52\%. Tingkat capaian rata-rata dari opportunistic behavior adalah sebesar $76,8 \%$.

\section{Self Esteem}

Berdasarkan tabel distribusi frekuensi variabel di atas, dari 108 responden yang diteliti terlihat bahwa tingkat capaian responden tertinggi yaitu pada item pernyataan nomor 2, yaitu nilai $80,74 \%$ dengan kategori sangat baik. Hal ini menunjukan bahwa para karyawan/pegawai pada OPD Kota Bukittinggi mengetahui hal-hal yang baik dalam dirinya. Sedangkan tingkat capaian responden terendah pada item pernyataan nomor 3, dengan pernyataansaya orang yang gagal, dengan nilai 34,81\%. Tingkat capaian rata-rata dari self esteem adalah sebesar 63,20\%.

\section{Uji Validitas dan Reliabilitas}

\section{Uji Validitas}

Untuk melihat validitas dari masing-masing item kuesioner, digunakan Corrected Item-Total Colleration. Jika item-item pertanyaan memiliki nilai koefisien korelasi $>0,3$ maka data dikatakan valid. Untuk masing-masing item variabel $\mathrm{X}_{1}, \mathrm{X}_{2} \mathrm{X}_{3}, \mathrm{X}_{4}$ dan $\mathrm{Y}$ semuanya di atas 0,3. Maka dapat dikatakan bahwa semua variabel dikatakan valid.

Tabel 4.9

\section{Nilai Corrected Item-Total Colleration Terkecil}

\begin{tabular}{|l|c|}
\hline \multicolumn{1}{|c|}{ Instrumen Variabel } & $\begin{array}{c}\text { Nilai Corrected Item-Total } \\
\text { colleration terkecil }\end{array}$ \\
\hline Budgetary Slack & 1 \\
\hline Tekanan Anggaran & 0,280 \\
\hline Ambiguitas Peran & 0,313 \\
\hline Opportunistic Behavior & 0,367 \\
\hline Self Esteem & 0,438 \\
\hline
\end{tabular}

Sumber : Data primer yang diolah, 2019

\section{Uji Reliabilitas}

Untuk uji reliabilitas instrumen, semakin dekat koefisien keandalan dengan 1,0 maka akan semakin baik. Secara umum, keandalan kurang dari 0,6 dianggap buruk, keandalan dalam 
kisaran 0,7 bisa diterima, dan lebih dari 0,8 adalah baik. Berikut ini merupakan tabel nilai cronbach's alpha masing-masing instrument.

Tabel 4.10

Nilai Cronbach's Alpha

\begin{tabular}{|c|c|c|}
\hline Instrumen Variabel & Nilai Cronboach's Alpha & Ket \\
\hline$(\mathrm{Y})$ & 0,743 & Reliable \\
\hline$\left(\mathrm{X}_{1}\right)$ & 0,707 & Reliable \\
\hline$\left(\mathrm{X}_{2}\right)$ & 0,701 & Reliable \\
\hline$\left(\mathrm{X}_{3}\right)$ & 0,702 & Reliable \\
\hline$\left(\mathrm{X}_{4}\right)$ & 0,736 & Reliable \\
\hline
\end{tabular}

Sumber: Data primer yang diolah, 2019

\section{Uji Asumsi Klasik}

\section{Uji Normalitas}

Uji normalitas bertujuan untuk menguji apakah dalam sebuah regresi, variabel pengganggu atau residual memiliki distribusi normal. Pengujian normalitas dapat dilakukan dengan menggunakan One Sample Kolmogorov-Smirnov Test, dengan taraf signifikan 0,05 atau 5\%. Jika signifikan yang dihasilkan > 0,05 maka distribusi datanya dikatakan normal. Sebaliknya jika signifikan yang dihasilkan $<0,05$ maka data tidak terdistribusi secara normal.

Tabel 4.11

Uji Normalitas

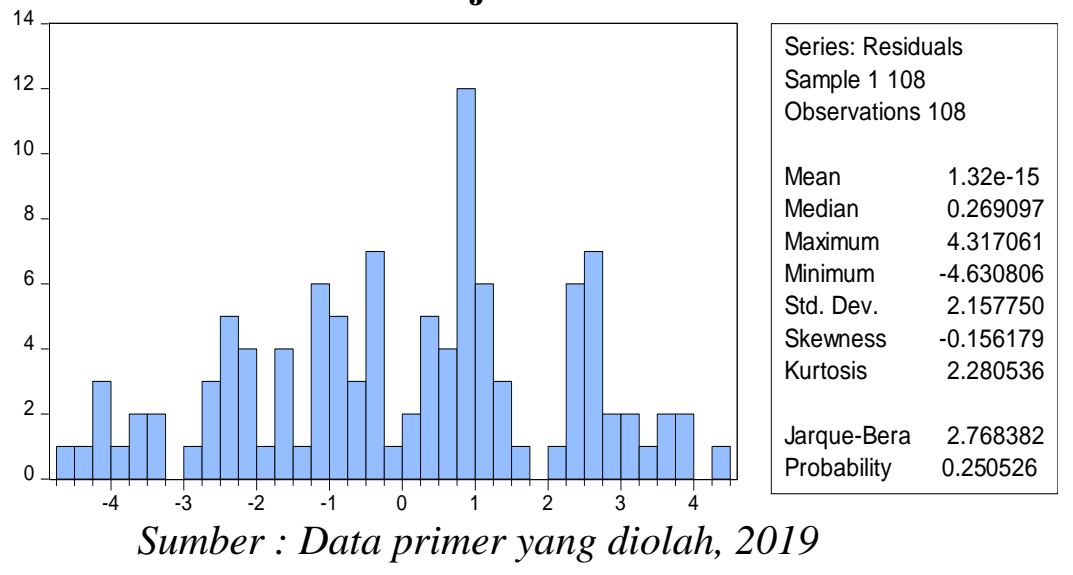

\section{Uji Multikolinearitas}

Uji multikolinearitas bertujuan untuk menguji apakah model regresi ditemukan adanya kolerasi antar variabel bebas atau independen. Untuk menguji adanya multikolinearitas dapat dilihat melalui nilai Variance Inflantion Factor (VIF) dan tolerance value untuk masing-masing variabel independen 


\section{Tabel 4.12 \\ Uji Multikolineritas}

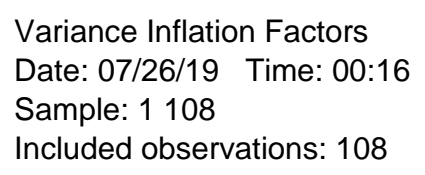

\begin{tabular}{cccc}
\hline \hline Variable & $\begin{array}{c}\text { Coefficient } \\
\text { Variance }\end{array}$ & $\begin{array}{c}\text { Uncentered } \\
\text { VIF }\end{array}$ & $\begin{array}{c}\text { Centered } \\
\text { VIF }\end{array}$ \\
\hline \hline C & 3.851651 & 86.00466 & NA \\
X1 & 0.002652 & 33.55569 & 1.393151 \\
X2 & 0.007218 & 48.12865 & 1.450430 \\
X3 & 0.007889 & 96.72095 & 1.575166 \\
X4 & 0.005088 & 113.0841 & 1.671915 \\
\hline \hline
\end{tabular}

Sumber : Data primer yang diolah, 2019

\section{Uji Heteroskedastisitas}

Uji heteroskedastisitas bertujuan untuk menguji apakah dalam sebuah model regresi terjadi ketidaksamaan variance dari residual atas satu pengamatan ke pengamatan yang lain. Adapun hasil pengujian dapat dilihat pada Tabel 4.13 berikut :

\section{Tabel 4.13}

\section{Uji Heterokedastisitas}

Heteroskedasticity Test: Glejser

\begin{tabular}{llll}
\hline \hline F-statistic & 1.238402 & Prob. F(4,103) & 0.2993 \\
Obs*R-squared & 4.955738 & Prob. Chi-Square(4) & 0.2919 \\
Scaled explained SS & 3.957051 & Prob. Chi-Square(4) & 0.4118 \\
\hline \hline
\end{tabular}

Sumber : Data primer yang diolah, 2019

\section{Analisis Regresi Berganda}

Untuk mengungkap pengaruh variabel yang dihipotesiskan dalam penelitian ini dilakukan melalui analisis regresi berganda dengan uji neweywest untuk menyembuhkan uji heterokedastisitas. Model ini digunakan terdiri dari empat variabel bebas yaitu tekanan anggaran $\left(\mathrm{X}_{1}\right)$, ambiguitas anggaran $\left(\mathrm{X}_{2}\right)$, opportunistic behavior $\left(\mathrm{X}_{3}\right)$ serta self esteem $\left(\mathrm{X}_{4}\right)$ dan satu variabel terikat yaitu budgetary slack (Y). Hasil pengolahan data yang menjadi dasar dalam pembentukan model penelitian ini ditunjukkan dalam tabel 4.14 berikut : 


\section{Tabel 4.14 \\ Analisis Berganda}

Dependent Variable: $Y$

Method: Least Squares

Date: 07/26/19 Time: 00:13

Sample: 1108

Included observations: 108

\begin{tabular}{ccccc}
\hline \hline & & & & \\
Variable & Coefficient & Std. Error & t-Statistic & Prob. \\
\hline \hline C & 2.282589 & 1.962562 & 1.163066 & 0.2475 \\
X1 & 0.024480 & 0.051497 & 0.475381 & 0.6355 \\
X2 & 0.078890 & 0.084957 & 0.928588 & 0.3553 \\
X3 & 0.122132 & 0.088819 & 1.375059 & 0.1721 \\
X4 & 0.188738 & 0.071331 & 2.645945 & 0.0094 \\
\hline \hline & & & & \\
R-squared & 0.228426 & Mean dependent var & 12.94444 \\
Adjusted R-squared & 0.198462 & S.D. dependent var & 2.456475 \\
S.E. of regression & 2.199249 & Akaike info criterion & 4.459299 \\
Sum squared resid & 498.1796 & Schwarz criterion & 4.583472 \\
Log likelihood & -235.8022 & Hannan-Quinn criter. & 4.509647 \\
F-statistic & 7.623336 & Durbin-Watson stat & 1.344888 \\
Prob(F-statistic) & 0.000020 & & \\
\hline \hline
\end{tabular}

Sumber : Data primer yang diolah, 2019

Berdasarkan Tabel 4.14 diatas, dapat dianalisis model estimasi sebagai berikut:

$$
\mathrm{Y}=0,247+0,635 \mathrm{X} 1+0,355 \mathrm{X} 2+0,172 \mathrm{X} 3+0,009 \mathrm{X} 4+e
$$

a. Nilai konstanta sebesar 0,24 mengindikasikan bahwa jika variabel independen yaitu tekanan anggaran, ambiguitas peran, opportunistic behavior dan self esteem adalah nol maka nilai budgetary slack adalah sebesar konstanta 0,24 .

b. Nilai koefisien tekanan anggaran sebesar 0,635 mengindikasikan bahwa peningkatan tekanan anggaran dalam satu satuan angka akan mengakibatkan peningkatan budgetary slack sebesar 0,635 satuan dengan asumsi variabel lain konstan.

c. Nilai koefisien ambiguitas peran sebesar 0,355 mengindikasikan bahwa peningkatan ambiguitas peran dalam satu satuan angka akan mengakibatkan peningkatan budgetary slack sebesar 0,355 satuan dengan asumsi variabel lain konstan.

d. Nilai koefisien opportunistic behavior sebesar 0,172 mengindikasikan bahwa peningkatan opportunistic behavior dalam satu satuan angka akan mengakibatkan penurunan budgetary slack sebesar 0,172 satuan dengan asumsi variabel lain konstan. 
e. Nilai koefisien self esteem sebesar 0,009 mengindikasikan bahwa peningkatan self esteem dalam satu satuan angka akan mengakibatkan peningkatan budgetary slack sebesar 0,009 satuan dengan asumsi variabel lain konstan.

4. Uji Hipotesis (t-Test)

a. Hipotesis Tekanan Anggaran $\left(\mathbf{X}_{1}\right)$

Hipotesis pertama dalam penelitian ini adalah terdapat pengaruh tekanan anggaran terhadap budgetary slack. Berdasarkan hasil olahan data Tabel 4.14, variabel tekanan anggaran $\left(\mathrm{X}_{1}\right)$ diperoleh nilai prob. $t_{\text {hitung }}$ sebesar 0,6355 . Karena nilai prob $t_{\text {hitung }}>0,05$ maka tidak terjadi signifikan antara variabel bebas dan variabel terikat.

\section{b. Hipotesis Ambiguitas Peran $\left(\mathbf{X}_{2}\right)$}

Hipotesis kedua dalam penelitian ini adalah terdapat pengaruh ambiguitas peran terhadap budgetary slack. Berdasarkan hasil olahan data Tabel 4.14, variabel ambiguitas peran $\left(\mathrm{X}_{2}\right)$ diperoleh nilai prob. thitung sebesar 0,3553 . Karena nilai prob thitung $>0,05$ maka tidak terjadi signifikan antara variabel bebas dan variabel terikat.

\section{c. Hipotesis Opportunistic Behavior $\left(\mathbf{X}_{3}\right)$}

Hipotesis ketiga dalam penelitian ini adalah terdapat pengaruh opportunistic behavior terhadap budgetary slack. Berdasarkan hasil olahan data Tabel 4.14, variabel opportunistic behavior $\left(\mathrm{X}_{3}\right)$ diperoleh nilai prob. thitungsebesar 0,1721 . Karena nilai prob thitung $>0,05$ maka tidak terjadi signifikanantara variabel bebas dan variabel terikat.

\section{d. Hipotesis Self Eteem $\left(\mathrm{X}_{4}\right)$}

Hipotesis keempat dalam penelitian ini adalah terdapat pengaruh self esteem terhadap budgetary slack. Berdasarkan hasil olahan data Tabel 4.14, variabel ambiguitas peran $\left(\mathrm{X}_{4}\right)$ diperoleh nilai prob. thitung sebesar 0,0094. Karena nilai prob thitung $<0,05$ maka terjadi signifikan antara variabel bebas dan variabel terikat.

\section{Koefisien Determinan $\left(\mathbf{R}^{2}\right)$}

Koefisien determinan menjelaskan variasi pengaruh variabel bebas terhadap variabel terikat.Berdasarkan hasil pengujian yang telah dilakukan, diperoleh nilai $R$-Squared sebesar 0,2284 . Hal ini berarti sebesar $22,84 \%$ budgetary slack dipengaruhi oleh variabel bebasnya yaitu tekanan anggaran $\left(\mathrm{X}_{1}\right)$, ambiguitas anggaran $\left(\mathrm{X}_{2}\right)$, opportunistic behavior $\left(\mathrm{X}_{3}\right)$, dan self esteem $\left(\mathrm{X}_{4}\right)$ sedangkan sisanya $77,16 \%$ dijelaskan oleh variabel lain di luar model atau tidak dimasukkan dalam penelitian.

\section{Uji Kelayakan Model (Uji-F)}

Uji kelayalakan model atau uji $\mathrm{F}$ (uji simultan) merupakan tahap awal untuk mengidentifikasi model regresi yang diestimasi apakah layak atau tidak. Nilai prob. F (Statistic) sebesar 0,0000 lebih kecil dari tingkat signifikansi yakni 0,05, sehingga dapat disimpulkan bahwa model regresi yang diestimasi layak digunakan untuk menjelaskan pengaruh tekanan anggaran (X1), ambiguitas peran (X2), opportunistic behavior (X3) dan self esteem (X4) terhadap budgetary $\operatorname{slack}(\mathrm{Y})$. 


\section{PEMBAHASAN}

\section{Pengaruh Tekanan Anggaran terhadap Budgetary Slack}

Berdasarkan hasil pengujian hipotesis dari penelitian ini diketahui bahwa tekanan anggaran tidak memiliki pengaruh terhadap budgetary slack. Dapat diartikan bahwa apabila terjadi kenaikan atau penurunan tekanan anggaran tidak akan mempengaruhi budgetary slack. Dengan demikian dapat disimpulkan bahwa hipotesis pertama $\left(\mathrm{H}_{1}\right)$ ditolak. Jika dilihat dari tabel distribusi frekuensi, nilai total capaian responden (TCR) terendah terdapat pada pernyataan "Terdapat sanksi ketika target anggaran tidak dapat dicapai" yaitu sebesar 63,70\% atau rata-rata 3,19 dengan kategori baik. Hal tersebut dapat disebabkan oleh atasan yang akan memberikan sanksi apabila dari bawahannya tidak dapat mencapai target anggaran yang telah ditetapkan sebelumnya.

\section{Pengaruh Ambiguitas Peran terhadap Budgetary Slack}

Berdasarkan hasil pengujian hipotesis dari penelitian ini diketahui bahwa ambiguitas peran tidak memiliki pengaruh terhadap budgetary slack. Dapat diartikan bahwa terjadi kenaikan atau penurunan ambiguitas peran, maka tidak akan mempengaruhi budgetary slack. Dengan demikian dapat disimpulkan bahwa hipotesis kedua $\left(\mathrm{H}_{2}\right)$ ditolak. Jika dilihat dari tabel distribusi frekuensi ambiguitas peran, nilai total capaian responden (TCR) terendah terdapat pada pernyataan "Saya merasa kurang jelas mengenai perkerjaan atau apa yang seharusnya saya lakukan dalam instansi" yaitu sebesar 56,30\% atau rata-rata 2,81 dengan kategori cukup. Hal tersebut dapat disebabkan oleh individu mengetahui kejelasan pekerjaan yang akan dilakukannya, sehingga rencana dan tujuan pekerjaan dapat dilaksanakan dengan baik.

\section{Pengaruh Opportunistic Behaviorterhadap Budgetary Slack}

Berdasarkan hasil pengujian hipotesis dari penelitian ini diketahui bahwa opportunistic behavior tidak memiliki pengaruh yang signifikan terhadap budgetary slack. Dapat diartikan bahwa apabila terjadi kenaikan atau opportunistic behavior maka tidak akan mempengaruhi budgetary slack. Dengan demikian dapat disimpulkan bahwa hipotesis ketiga $\left(\mathrm{H}_{3}\right)$ diterima. Jika dilihat dari tabel distribusi frekuensi opportunistic behaviour, nilai total capaian responden (TCR) terendah terdapat pada pernyataan saya keputusan dan tindakan instansi merupakan usaha untuk mempertahankan status quo, yaitu sebesar 58,52\% atau rata-rata 2,68 dengan kategori baik. Hal tersebut dapat disebabkan oleh individu atau instansi tidak ingin meninggalkan zona nyaman dan tidak menyukai adanya perubahan tersebut.

\section{Pengaruh Self Esteem terhadap Budgetary Slack}

Berdasarkan hasil pengujian hipotesis dari penelitian ini diketahui bahwa self esteem memiliki pengaruh signifikan positif terhadap budgetary slack. Dapat diartikan bahwa apabila terjadi kenaikan self esteem maka akan mempengaruhi budgetary slack. Dengan demikian dapat disimpulkan bahwa hipotesis keempat $\left(\mathrm{H}_{4}\right)$ diterima.Jika dilihat dari tabel distribusi frekuensi self esteem, nilai total capaian responden (TCR) terendah terdapat pada pernyataan "Saya orang yang gagal" yaitu sebesar 34,81\% atau rata-rata 1,74 dengan kategori cukup. Hal tersebut dapat disebabkan bahwa individu yang bekerja di OPD Kota Bukittinggi mereka yakin bahwa mereka bukanlah orang yang gagal, sehingga rencana dan tujuan pekerjaan dapat dilaksanakan dengan baik. 


\section{KESIMPULAN, KETERBATASAN DAN SARAN \\ Kesimpulan}

Dari hasil pengolahan data dan pembahasan terhadap hasil penelitian antara variabel bebas terhadap varaibel terikat yang telah diuraikan, maka dapat ditarik kesimpulan sebagai berikut:

a. Tekanan anggaran tidak memiliki pengaruh terhadap budgetary slack.

b. Ambiguitas anggaran tidak memiliki pengaruh terhadap budgetary slack.

c. Opportunistic behavior tidak memiliki pengaruh terhadap budgetary slack.

d. Self esteem memiliki pengaruh terhadap budgetary slack.

\section{Keterbatasan}

Meskipun peneliti telah berusaha merancang dan mengembangkan penelitian ini sedemikian rupa, namun masih terdapat beberapa keterbatasan dalam penelitian mengenai pengaruh tekanan anggaran, ambiguitas peran, opportunistic behavior, dan self esteem terhadap budgetary slack di Kota Bukittinggi.

a. Wilayah penelitian hanya terbatas pada OPD yang terdapat di Kota Bukittinggi sehingga hasil penelitian belum dapat digeneralisasi kesemua objek secara keseluruhan.

b. Dimana dari model penelitian yang digunakan, diketahui bahwa variabel penelitian yang digunakan hanya dapat menjelaskan sebesar $22,84 \%$, sedangkan sisanya sebesar $77,16 \%$ dijelaskan oleh faktor lain yang tidak diteliti dalam penelitian ini. Sehingga variabel penelitian yang digunakan belum dapat menjelaskan sepenuhnya pengaruh terhadap budgetary slack.

\section{SARAN}

Berdasarkan kesimpulan dari hasil penelitian maka penulis mengemukakan saran-saran sebagai berikut:

a. Bagi penelitian selanjutnya agar dapat memperluas cakupan wilayah penelitian, tidak hanya OPD di wilayah Kota Bukittinggi, tetapi juga bisa meliputi daerah lain.

b. Penelitian ini masih terbatas pada tekanan anggaran, ambiguitas peran, opportunistic behavior, dan self esteem terhadap budgetary slack. Untuk penelitian selanjutnya dapat dilakukan perubahan variabel penelitian untuk menemukan variabel-variabel lain yang berpengaruh lebih kuat terhadap budgetary slack.

c. Penelitian ini masih memiliki keterbatasan, yaitu ada beberapa responden yang mengisi kuesioner penelitian yang tidak sesuai dengan kondisi yang sesungguhnya, maka untuk penelitian sebelumnya dapat disertai dengan penelitian kualitatif dan penggantian teknik pengambilan sampel penelitian. Serta pemaparan kasus pada kuesioner pernyataan negatif, karena kurang pahamnya responden menjawab tidak tepat. Bagi peneliti selanjutnya sebaiknya lebih banyak memaparkan pertanyaan positif.

\section{DAFTAR PUSTAKA}

Alwisol. 2004. Psikologi Kepribadian Edisi Revisi. Malang: UMM Press.

Anthony, Robert N dan Vijay Govindarajan. 2005. Sistem Pengendalian Manajemen buku dua. Terjemahan Kurniawan Tjakrawala. Jakarta: Salemba Empat.

Apriandi. (2010). "pengaruh Informasi Asimetri Terhadap Hubungan Antara Anggaran Partisipatif dengan Budgetary Slack". Fakultas Ekonomi dan Bisnis Universitas Hasanudin. 
Atwater EastWood, dan Duffy, K.G. 1990. Psychology for living: Adjusment, Growht and Behavior today ( $5^{\text {th }}$ edition). New Jersey: Prentice-Hall, Inc.

Cahyono, Dwi. 2008. Presepsi Ketidakpastian Lingkungan, Ambiguitas Peran, dan konflik Peran sebagai Mediasi Antara Program Monotoring dengan Kepuasan Kerja, Prestasi Kerja dan Niat Ingin Pindah. Tesis. Semarang: Universitas Diponegoro.

Coopersmith. 1990. The Antecendents of Self Esteem. USA. W.H. Freeman and Company.

Ghozali, Imam. 2007.Aplikasi Analisis Multivariate dengan Program SPP. Semarang: Universitas Dipenegoro.

Huruman, Tendi dan Rahayu, Sri. 2007. Penyusunan Anggaran Perusahaan. Edisi Kedua. Yogyakarta: Graha Ilmu.

Kreitner, Robert dan Angelo Kinicki. 2014. Organizational Behavior-Ed. 5. Boston: McGrawHill.

Kuncoro, Mudrajad. 2003. Metode Riset Untuk Bisnis \&Ekonomi. Jakarta: Erlangga.

Mardiasmo. 2002. Akuntansi Sektor Publik. Yogyakarta: Andi.

Nafarin, M. 2015. Penganggaran Perusahaan, Jakarta: Salemba Empat.

Nordiawan. dkk . 2009. Akuntansi Pemerintahan. Jakarta: Salemba Empat.

Pratama, R. 2013. Pengaruh Partisipasi Anggaran Terhadap Senjangan dengan Komitmen Organisasi, dan Motivasi Sebagai Pemoderasi. Skripsi. FE UNP.

Puspitasari, Mita. 2006. Hubungan Antara Obesitas dan Self Esteem pada Remaja Akhir. Skripsi tidak Diterbitkan. Malang: Fakultas Ilmu Pendidikan Universitas Negeri Malang.

Ratmono, Dwi Dan Sholihin, Mahfud. 2015. Akuntansi Keuangan Daerah Berbasis Akrual. Yogyakarta: UPP STIM YKPN

Rivai V. H. \&Mulyadi D. 2011. Kepemimpinan dan Perilaku Organisasi. Jakarta: Rajawali Pers. Rudianto. 2009. Penganggaran Konsep dan Teknik Penyusunan Anggaran. Jakarta: Erlangga.

Samad, Sudarman. 2009. Pengaruh Partisipasi Anggaran terhadap Senjangan Anggaran: studi pada seluruh SKPD di Provinsi Gorontalo. Tesis. Universitas Gadjah Mada.

Sugiyono, 2009, Metode Penelitian Kuantitatif, Kualitatif dan R\&D, Bandung : Alfabeta.

Sugiyono. 2004. Metode Penelitian Bisnis. Bandung: Alfabeta

Sugiyono, 2006, Metode Penelitian Kuantitatif, Kualitatif dan R\&D, Bandung : Alfabeta.

Supanto. 2010. "Analisis Pengaruh Partisipasi Penganggaran terhadap Budgetary Slack dengan Informasi Asimetri, Motivasi, Budaya Organisasi sebagai Pemoderasi”. Tesis S2. Universitas Dipenogoro.

Triana, maya dkk.2012. Pengaryh partisipasi anggaran, Budget Enmphasis, dan Locus of Control Terhadap Slack Anggaran. Jurnal Akuntansi Vol. 1 No. 1 September 2012. 